\title{
C-CELLS IN COLLOID GOITER
}

\author{
Marcus A. Lima, Fabiana S. Tiveron, Vitorino M. Santos, Lilian M. B. Lima, \\ Gilberto P. Silva and Maria F. Borges
}

LIMA MA et al. - C-cells in colloid goiter. Rev. Hosp. Clín. Fac. Med. S. Paulo 58(6):310-314, 2003.

PURPOSE: The aim of this investigation was to quantitatively evaluate C-cells in colloid goiters, analyzing 36 thyroids that were obtained through thyroidectomy from 24 patients with goiter and 12 normal glands from adult patients without thyroid disease, which were used as the control group.

MATERIAL AND METHODS: On average, 6 different thyroid areas were sampled and labeled by immunohistochemistry with a monoclonal anticalcitonin antibody, utilizing the avidin-biotin-peroxidase complex. Ccells were counted in fields measuring 1 square centimeter, and the mean number of cells per field was then calculated. Data were statistically analyzed using the Mann-Whitney test.

RESULTS: In the colloid goiter group, the number of C-cells ranged from 0 to 23 per field, while in normal controls they ranged from 20 to 148 per field.

CONCLUSIONS: These results demonstrate a significant decrease of C-cell number in the colloid goiter group compared with control group, indicating that the hyperplastic process is restricted to follicular cells, to the detriment of C-cells, which probably cease to receive trophic stimuli.

\section{DESCRIPTORS: C-cells. Thyroid. Colloid goiter. Calcitonin.}

Colloid goiter is a hyperplastic disease of thyroid follicular cells due to multifactorial causes. One of the most accepted and well-documented hypotheses of etiology is a reduced production of thyroid hormone and consequent increased level of thyroid stimulant hormone (TSH), which initially causes gland hyperplasia, followed by the development of multiple monoclonal adenomas ${ }^{1-3}$. In multinodular goiters, each individual nodule may respond in a diverse way under TSH influence and, as a physiologic structure, is dependent on genetic characteristics inherited from the stem cells ${ }^{4}$. Among the causal factors of colloid goiter, foods that block the hormonal synthesis, mutations in TSH receptors, iodine-poor diets, globulin stimulation of thyroid development, growth hormone $(\mathrm{GH})$, insulin-like growth factor (IGF-1), and genetic factors are implicated ${ }^{3}$.

In addition to follicular cells, in the thyroid gland there are C-cells, which are producers of calcitonin, an important hormone acting on calcium homeostasis ${ }^{5}$. These cells are heterogeneously distributed in the gland, with higher concentrations in the medial and superior thirds of the thyroid lateral lobe, and they are scanty in the isthmus $^{6,7}$. Immunohistochemical and ultrastructural studies have shown that Ccells occupy, exclusively, intrafollicular sites and are separated from the interstitium by follicular basal lamina ${ }^{8,9}$.

From the Disciplines of Endocrinology, Internal Medicine and Biostatistics, Faculty of Medicine of the Triângulo Mineiro, Uberaba, Minas Gerais, Brazil. Received for publication on April 02, 2003.
The possible influence upon Ccells of thyroid hormones and other factors that control thyroid function such as iodine remains controversial ${ }^{10}$. Several studies indicate that TSH and TSH-releasing hormone (TRH) also participate in $\mathrm{C}$-cell regulation ${ }^{10}$. Some authors have found mRNA for TSH and TRH receptors, as well as for thyroglobulin and thyroperoxidase in $\mathrm{C}$-cells ${ }^{11}$. Moreover, other studies showed that high levels of TRH would deliver calcitonin in these cells, similar to the effect of pentagastrin ${ }^{12}$. These data seem to indicate some interactions between thyroid follicular cells and C-cells with respect to delivering thyroid hormone and calcium metabolism, which merit further investigation.

In addition to these functional aspects, it has been shown that high levels of TSH may cause C-cell hyperpla- 
$\operatorname{sia}^{13,14}$. Moreover, quantitative changes in C-cells may occur in conditions such as familial hyperplasia associated with multiple endocrine neoplasia and Hashimoto's chronic thyroiditis ${ }^{15,16}$. Nevertheless, quantitative studies of Ccells in colloid goiter are scanty. Inoue, in $1990^{17}$, observed through a histochemistry method a reduced number of C-cells in colloid goiters, when compared to normal thyroids.

The aim of this study was to quantify C-cells in colloid goiters to evaluate a possible role of these cells in the pathogenesis of goiters.

\section{MATERIALS AND METHODS}

Case selection. Thyroid samples obtained from patients with colloid goiters who underwent thyroidectomy were systematically studied in the Pathologic Anatomy Laboratory from the Association of Combat of Cancer from Central Brazil (ACCCB), in the city of Uberaba In addition to esthetic reasons, thyroidectomy was indicated because of esophageal or tracheal compression caused by thyroid hyperplasia.

Twenty-four cases of colloid goiters from 21 female and 3 male patients (mean age: 46.7) with normal thyroid function were studied and compared to 12 normal thyroids obtained from necropsies of 9 female and 3 male patients (mean age: 60.1).

Thyroid examination. Tissue fragments were fixed in formalin $3.7 \%$, and samples obtained from 6 different areas of the goiters, measuring one square centimeter, were embedded in paraffin, cut at $4 \mathrm{~mm}$, and stained with hematoxylin-eosin (HE). In 6 different areas from normal thyroids, one region of the inferior, medium and superior thirds of each lobe was also examined.

Immunohistochemistry. The anticalcitonin monoclonal antibody (M3509), diluted at 1:1500, was utilized. Tissue sections were deparaffini- zed and hydrated before a pretreatment with a buffer solution of sodium citrate $0.01 \mathrm{M}, \mathrm{pH} 6.0$, in a microwave oven, during 2 cycles of 9 minutes at $900 \mathrm{~W}$. In each cycle, the volume was completed with the buffer solution to avoid tissue dryness. Next, the sections were rinsed in current water, washed in $3 \%$ oxygen peroxide solution for 15 minutes, rinsed again in current water, and then maintained in a phosphate buffer solution (PBS), $\mathrm{pH} 7.4$, for 10 minutes. In sequence, sections were incubated with the primary antibody for 22 hours at $4^{\circ} \mathrm{C}$, before utilizing the detection system with avidin-biotin (KO 675). The revelation was performed using the chromogen 3-amine9-ethyl-carbazole (AEC A-5754, Sigma), and Mayer's hematoxylin was used in the counterstaining of the sections. Fragments of a thyroid medullar carcinoma from an adult patient were utilized as positive controls, while negative controls were samples of each case to be evaluated, without using the primary antibody.

Cell counting. Areas of one square centimeter from sections prepared for histochemistry study were observed through 100X magnification. C-cells were counted in 6 different areas, taking in account the coloration (reddened by chromogen AEC), morphology, and topography. In each case, the number of follicles per area was also counted. The density of C-cells was determined for each patient, relating the number of cells observed among all sections per unit of thyroid tissue area, expressed as number of cells per square centimeter. A single observer determined the mean number of $\mathrm{C}$ cells per field. Thyroid samples showing adenomatous hyperplasia, edema, hemorrhage, or fibrosis were not included in the present study.

Statistical analysis. The analysis of variance (Mann-Whitney test) showed no significant difference in number of follicles per area $(p=0.40)$ between the group of patients with colloid goiter and normal controls. Therefore, the analysis was performed considering the number of $\mathrm{C}$-cells in 6 areas for each patient with colloid goiter and normal thyroid. The supposition of normality of the data and variance homogeneity were verified through the tests of KolmogorovSmirnov and Bartlett, respectively ${ }^{18}$. The Mann-Whitney test was applied to compare the groups with respect to the number of C-cells. The significance level considered was $\mathrm{a}=0.05$.

\section{RESULTS}

C-cells counted in sections of colloid goiters, labeled with anticalcitonin antibody, showed their presence in numbers ranging from 1.16 to 23 per field (one square centimeter) in 15 cases $(62.5 \%)$ and were absent in 6 different areas (one square centimeter) in 9 cases $(37.5 \%)$ as shown in table 1.

Table 1 - Frequency of C-cells in samples from 24 colloid goiters.

\begin{tabular}{cc}
\hline Case no. & $\begin{array}{c}\text { C-cells / 1 square } \\
\text { centimeter }\end{array}$ \\
\hline 1 & 21 \\
2 & 11 \\
3 & 0 \\
4 & 1.16 \\
5 & 5.25 \\
6 & 0 \\
7 & 0 \\
8 & 3.5 \\
9 & 5.66 \\
10 & 14 \\
11 & 8 \\
12 & 0 \\
13 & 7.5 \\
14 & 21.5 \\
15 & 10.33 \\
16 & 0 \\
17 & 0 \\
18 & 3 \\
19 & 0 \\
20 & 7 \\
21 & 23 \\
22 & 0 \\
23 & 18 \\
24 & 0 \\
\hline
\end{tabular}


C-cells were observed with higher frequency, 20 to 148 per field, in thyroids of normal controls, with a mean number of 35.2 per field (Table 2). In these glands, C-cells frequently ap-

Table 2 - Frequency of C-cells in samples from 12 normal thyroids.

\begin{tabular}{cc}
\hline Case no. & $\begin{array}{c}\text { C-cells / 1 square } \\
\text { centimeter }\end{array}$ \\
\hline 1 & 21.25 \\
2 & 123 \\
3 & 148 \\
4 & 27.5 \\
5 & 43 \\
6 & 20 \\
7 & 51 \\
8 & 32 \\
9 & 111 \\
10 & 28 \\
11 & 11 \\
12 & 64 \\
\hline
\end{tabular}

peared as small clusters of more than 10 cells, while in cases of colloid goiter they were isolated and scattered through the hyperplastic tissue.

The statistical analysis showed a significant reduction of C-cell number in colloid goiters when compared to normal thyroids $(p<0.05)$. As showed in table 3, C-cell number in the 6 areas was significantly greater in patients with normal thyroids (median: 210) than in patients with colloid goiter (median: 40).

\section{DISCUSSION}

Our data confirm the results described by Inoue ${ }^{17}$, showing a reduction of C-cells in colloid goiters. In

Table 3 - Comparative number of C-cells counted in 1 square centimeter areas from samples of 24 colloid goiter and 12 normal thyroid patients (Mann-Whitney test).

\begin{tabular}{lcccccccc}
\hline Groups & Cases & Minimum & Maximum & Mean & SD & Median & U & $p$ value \\
\hline CG & 24 & 0 & 23.0 & 6.7 & 7.7 & 4.4 & 10.5 & $<0.0001$ \\
Normal & 12 & 11.0 & 148.0 & 56.7 & 45.7 & 37.5 & & \\
\hline
\end{tabular}

CG: colloid goiter group; Normal: control group; SD: standard deviation.

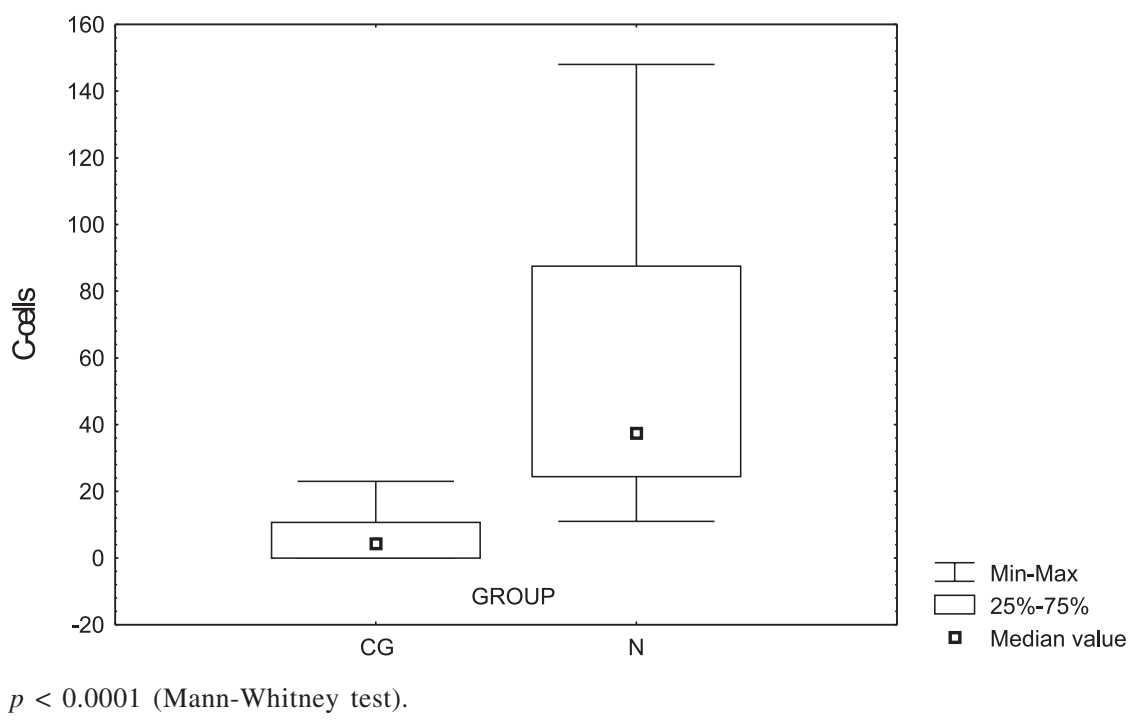

Figure 1 - Median comportment of C-cells in the colloid goiter group and normal control. normal thyroids, these cells are predominantly found in the superior and medial thirds of thyroid lateral lobes, and may as appear single cells or as forming small clusters positioned intrafollicularly ${ }^{8,9,17}$. The distribution of these cells in the gland is variable from one individual to another and may change with age ${ }^{6}$ and gender ${ }^{19}$.

C-cell hyperplasia has been described in association with tumors ${ }^{20,21}$ and colloid goiters ${ }^{22}$; however, the involved physiopathologic mechanisms are not entirely clear. Experimental studies $^{23}$ have suggested that hypersecretion of TSH, a common change observed in colloid goiters, can play a role in C-cell hyperplasia, although this finding is yet to be confirmed in humans. Barbot et al. ${ }^{24}$ suggested that TSH regulates calciotonin synthesis similarly to the thyroid hormone regulation. Microscopic studies of thyroids from patients with goiters and elevated calcitonin blood levels show C-cell hyperplasia ${ }^{25}$; however, the pathogenesis is still unclear.

Studies of colloid goiters suggest that thyroid growth factors do not influence C-cells. This hypothesis is favored by the absence of C-cells in nodules of relapsing goiters, in which the tissue proliferation is predominantly asymmetric, differing from the homogeneous and regular hyperplasia of thyroid lobular parenchyma ${ }^{26}$.

Otherwise, colloid goiter is a condition affecting, more frequently, the lower portions of the gland, while Ccells are located mainly in the superior and medial thirds of thyroid lateral lobes ${ }^{37,19}$. Moreover, since C-cell hyperplasia is more common in males and the vast majority of patients with colloid goiter (CG) are females, this fact could have a role in the reduced number of C-cells found in samples from colloid goiters. However, in this study there was no statistical difference in female distribution between CG and normal control group. 
LIMA MA e col. - Células c em bócio colóide. Rev. Hosp. Clín. Fac. Méd. S. Paulo 58(6):310-314, 2003.

OBJETIVO: Pesquisar, quantitativamente, as células $\mathrm{C}$ em bócio colóide com o propósito de investigar a relação destas células na patogênese do bócio.

MÉTODO: Foram analisadas 35 tiróides obtidas de tiroidectomia, sendo 24 de pacientes com bócio colóide e 11 tiróides normais de adulto usadas como controle. Seis diferentes áreas foram amostradas em média e coradas com o anticorpo monoclonal anticalcitonina. As células $\mathrm{C}$ foram contadas em campos de $1 \mathrm{~cm}^{2}$ e o número médio de células/campo foi calculado. Os dados foram estudados estatisticamente pelo teste de Kruskal-Wallis.

RESULTADOS: $\mathrm{O}$ número de células $\mathrm{C}$ variou de 0 a $23 / \mathrm{cm}^{2}$ em bócio colóide e em tiróides normais de 20 a $148 / \mathrm{cm}^{2}$.
CONCLUSÕES: Os resultados demonstraram redução significativa no número de células $\mathrm{C}$ em bócio colóide comparando com tiróides normais, indicando que o processo hiperplásico é restrito às células foliculares em detrimento das células $\mathrm{C}$, as quais, provavelmente, deixam de receber estímulos tróficos e se degeneram.

DESCRITORES: Bócio Colóide. Células C. Calcitonina. Tiróide.

\section{REFERENCES}

1. Studer H, Peter HJ, Geber H. Natural heterogeneity of thyroid cells: the basis for understanding thyroid function and nodular goiter growth. Endocr Rev 1989; 10: 125.

2. Studer H, Ramelli F. Simple goiter and its variants euthyroid and hyperthyroid multinodular goiters. Endocr Rev 1982; 3: 40.

3. Medeiros-Neto GA. Bócio Multinodular. Arq Bras Endocrinol Metab 1998; 42: 286-291.

4. Knobel M, Bisi H, Peres CA, Medeiros-Neto GA. Correlated functional and morphological aspects in human multinodular simple goiter tissues. Endocr Pathol 1993; 4: 205.

5. Borges MF, Abelin NMA, Toledo SPA. Calcitonin: physiology and deficiency. Arq Bras Endocrinol Metabol 1996; 40: 6782.

6. Gibson WGH, Peng TC, Croker BP. Age-associated C-cell hyperplasia in the human thyroid. Am J Pathol 1982; 106: 338-393

7. Lima MA, Santos BM, Tiveron FS, et al. C cells in normal thyroid aspirates. Acta Cytol 1999; 43: 558-562.

8. De Lellis RA, Wolfe HJ. The pathobiology of the human calcitonin (C)-cell: a review. Pathol Ann 1981; 16: 25-52.

9. Mc Millan PJ, Hooker WM, Deftos LJ. Distribution of calcitonin - containing cells in the human thyroid. Am J Anat 1974; 140:73-80.

10. Nunez EA, Gershon MD. Thyrotropin-induced thyroidal release of 5-hydroxytryptamine and accompanying ultrastructural changes in parafollicular cells. Endocrinology 1983; 113: 309317 .
11. Elisei R, Pinchera A, Romei C, et al. Expression of thyrotropin receptor (TSH-R), thyroglobulin, thyroperoxidase, and calcitonin messenger ribonucleic acids in thyroid carcinomas: evidence of TSH-R gene transcript in medullary histotype. J Clin Endocrinol Metabol 1994; 78: 867-871.

12. Oishi S, Yamauchi J, Fujimoto Y, et al. Calcitonin release from medullary thyroid carcinoma by thyrotropin-releasing hormone: comparison with calcium injection. Acta Endocrinol 1992; 126: 325-328.

13. Kalisnik M, Vraspir-Porenta O, Khan-Lindtner T, et al. The interdependence of the follicular, parafollicular and mast cells in the mammalian thyroid gland: a review and a synthesis. Am J Anat 1988; 183: 148-157.

14. Nayar RP, Oslapas R, Paloyan E. Age related correlation between serum TSH and thyroid C cell hyperplasia in Long-Evans rats. J Exp Pathol 1989; 4: 87-95.

15. Borges MF, Abelin NMA, Menezes FOM, et al. Calcitonin deficiency in early stages of chronic autoimmune thyroiditis. Clin Endocrinol 1998; 49: 69-75.

16. Lima MA, Santos BM, Borges MF. Quantitative analysis of C cells in Hashimoto's thyroiditis. Thyroid 1998; 8: 505-509.

17. Inoue S, Yokoyama S, Nakayama I, et al. An immunohistochemical study of calcitonin-containing cells in benign and malignant thyroid lesions. Acta Pathol Jpn 1990; 40: 187-192.

18. Byrkit AR. Statistics Today: A comprehensive introduction. California, Benjamin Cumming Publishing Company, 1977.

19. Guyetant S, Rousselet MC, Dungan M, et al. Sex-related C cell hyperplasia in the normal human thyroid. A quantitative autopsy study. J Clin Endocrinol Metab 1997; 82: 42-47. 
20. Scopsi L, Dipalma S, Ferrari C, et al. C-cell hyperplasia accompanying thyroid diseases other than medullary carcinoma: An immunocytochemical study by means of antibodies to calcitonin and somatostatin. Mod Pathol 1991; 4: 297-304.

21. Albores-Saavedra J, Krueger JE. C-cell hyperplasia and medullary thyroid microcarcinoma. Endocr Pathol 2001; 12: 365-378.

22. Small PK, Smith D. Sporadic medullary thyroid carcinoma associated with multinodular goiter. J R Coll Surg Edinb 1997; 42: 199-200.

23. Katoh R. Experimental thyroid tumorigenesis induced by 3amino-1,2,4-triazole (AT) and diisopropanolnitrosamine (DIPN). J Iwate Med Assoc 1983; 13: 379-405.
24. Barbot N, Guyetant S, Beldent V, et al. Thyroidite chronique auto-immune et hyperplasie des cellules C. Ann Endocrinol 1991; 52: 109-112.

25. Pantazi H, Papetrou PD. Calcitonin levels are similar in goitrous euthyroid patients with or without thyroid antibodies, as well as in hypothyroid patients. Eur J Endocrinol 1998; 138: 530535 .

26. Rink T, Hartmut F, Schroth HJ, et al. Development of the parafollicular cells in recurrent goiter. Eur J Endocrinol 2001; 144: 485-489. 